\title{
COMPARISON OF PREVALENCE OF PERIODONTITIS WITH DIFFERENT INDICES IN POPULATION OF DISTRICT GHAZIABAD
}

\author{
Vimal Kumar ${ }^{1}$, Pallak Arora ${ }^{2}$, Manish Khatri ${ }^{3}$, Shivani Sharma ${ }^{4}$, Sumit Malhotra ${ }^{5}$, Vandana Sharma \\ ${ }^{1}$ Senior Lecturer, Department of Periodontics, Kalka Dental College Hospital and Research Centre, Uttar Pradesh, India \\ ${ }^{2}$ Reader, Department of Oral Medicine \& Radiology, Kalka Dental College Hospital and Research Centre, Uttar Pradesh, India \\ ${ }^{3}$ Professor, Department of Periodontics, IDST Dental College, Uttar Pradesh, India \\ ${ }^{4}$ Reader, Department of Periodontics, Kalka Dental College Hospital and Research Centre, Uttar Pradesh, India \\ ${ }^{5}$ Professor, Department of Periodontology, Kalka Dental College Hospital and Research Centre, Uttar Pradesh, India \\ ${ }^{6}$ Senior Lecturer, Department of Oral Pathology, Kalka Dental College Hospital and Research Centre, Uttar Pradesh, India
}

\begin{abstract}
\begin{tabular}{r|r}
\hline & ABSTRACT
\end{tabular}
Objective: To estimate the prevalence of periodontal disease with different indices. Methods \& Materials: The study population consisted of multistage stratified random sample of 1300 subjects from total population of district Ghaziabad. A cross-sectional study was conducted with multi stage stratified random sampling techniques to select the sample population. The subjects were divided into different age groups and the periodontal assessment was made on the basis of CPITN index and ESI Index. Results: The CPITN has shown to estimate incorrect periodontal disease prevalence because of its underestimation of the disease severity. A huge difference was noticed in the prevalence rate of periodontitis when subjects were examined with ESI index. Conclusion: Periodontal disease was found to be highly prevalent in the study population and severity of disease increased with age. More number of subjects in younger age group were found to be healthy.
\end{abstract}

Keywords: CPITN, ESI, Periodontal disease, Prevalence

\section{INTRODUCTION}

Periodontal disease and dental caries are the main chronic infectious diseases of the oral cavity and the principal cause of tooth loss in humans. Periodontal diseases include a group of chronic inflammatory diseases that affect the periodontal supporting tissues of teeth and encompass destructive and nondestructive diseases. ${ }^{1}$

Periodontal diseases have a number of characteristics that must be considered in conducting epidemiological studies. Periodontitis appears to be an infectious disease that has many characteristics of a chronic disease; there is a need for dental prophylaxis and instruction in the use of oral hygiene procedures. Most forms progress slowly and some aspects are not reversible, even if the infective agent is removed. Thus, the incidence and prevalence rates of periodontitis may be quite different. In addition, the disease exhibits a pattern of multiple attacks, often affecting one or more sites around one or more teeth resulting in the epidemiological measures of the disease being very sensitive to tooth loss and creates a problem of repeated nonindependent measures. The way, in which the disease progresses is not clear, creating problems in measurement of active disease and in defining a case. ${ }^{2,3}$

Ainamo $\mathrm{J}$ et $\mathrm{al}^{4}$ raised the question of validity of the indices used to measure periodontal diseases at community level. Definite differences were showed on comparing the three indices: full mouth six site examination, Ramfjord index and Community Periodontal Index for Treatment Needs.

National surveys have estimated that moderate periodontitis affected about one half of the United States population. More advanced periodontal destruction $(>5 \mathrm{~mm}$ 
loss of attachment in one site) affected only about 1 in 8 people. Advanced destruction was almost nonexistent among younger adults but increased with age, reaching a prevalence of over one third among people aged 5564 years. These estimates, based on the 1985-1986 NIDR survey, are probably lower than the actual prevalence due to the impact of partial recording. The amount of the underestimate is unknown, but even if the true prevalence is double the estimate, only $25 \%$ of the population had advanced periodontitis in 19851986. Periodontitis may not be as widespread as once thought, and perhaps we are entering an era when almost everyone can maintain their dentition throughout their life. ${ }^{5}$ Very few recent studies conducted in India have compared prevalence of periodontal diseases in urban and rural areas. Rao et $\mathrm{al}^{6}$ carried out one such study in Sewagram in urban, rural and tribal school children. Bleeding, calculus and abscess were taken as prevalence criteria. It was found that there was no significant difference in prevalence of periodontal diseases in urban \& rural areas for the age group studied.

Thus in this epidemiological study an attempt has been made to compare the accuracy and reliability of Community Periodontal Index of Treatment Needs (C.P.I.T.N) and Extent and Severity Index (E.S.I) among the population of district Ghaziabad (Uttar Pradesh, India).

\section{MATERIALS AND METHOD}

A cross-sectional study was conducted in which multi stage stratified random sampling techniques were used to select the sample population as under:

\section{1) First Stage}

Out of four Tehsils of District Ghaziabad, two were selected by simple randomization (Modi Nagar and Hapur).

\section{2) Second Stage}

The selected Tehsils were further divided into three zones by the systemic randomization. (Modi Nagar, Bhojpur and Hapur).

\section{3) Third Stage}

Six wards were selected (Multanipura, Fafranabasti, Adarshnagar, Modipone, Govindpuri, Modisteel Colony) from Modinagar, Ten villages (Sara, Yakutpurmavi, Kadrabad, Rori, Saidpur, Phaphrana,
Sikrikhurd, Bhakharwa, Khanjarpur and Bhojpur) from Bhojpur, and Seven villages (Anwarpur, Abdullahpur Mori, Upada, kurana-kamalpur, Nizampur, Firozpur and Firozabad) from Hapur by Fisher and Yates table of Random Numbers. ${ }^{6}$

\section{4) Fourth Stage}

Full information was collected from the ward members and village Pradhans about the areas to be examined like the total number of residents, age groups etc. The study population consisted of random sample of 1300 subjects from total population of district Ghaziabad. The selected subjects for the study were informed briefly about the study plans and were asked to sign a consent form. Valuable information from every patient was collected via structured questionnaire which consisted of questions of our interests like age, gender, area etc. Every individual, along with routine dental examination, was assessed for the periodontal disease status by using sterilized Mouth Mirror; CPITN-C Probe for Community Periodontal Index of Treatment Needs (introduced by Jukka Ainamo, George Beagrie, David Bormas, Jean Martin and Jennifer Sardo-Infirri in 1982) ${ }^{8}$ and Williams graduated Periodontal probe for Extent and Severity Index (introduced by Carlos JP et al in 1986). ${ }^{9}$

The statistical analysis was done using the ChiSquare test; Significant association was observed between males and females in rural and urban area. The formula used for $\mathrm{CHI}$-square test was:

$$
\frac{\chi^{2}="(\mathrm{O}-\mathrm{E})^{2}}{\mathrm{E}}
$$

Where: $\mathrm{O}=$ Observed Value and $\mathrm{E}=$ Expected Value

\section{RESULTS}

The study sample was divided into 4 age groups - in the range of 20-30 years, 30-40 years, $40-50$ years and 50 years and above. Total sample size was 1300 , out of this; 642 subjects were from rural areas and 658 subjects were from urban areas. Selected subjects were further distributed according to area, age and gender into different severities of C.P.I.T.N. and E.S.Iindex.

When a comparison of C.P.I.T.N scores \{Table No 1 (A) \& (B) $\}$ in rural and urban areas among 20-30 yrs 
Table No. 1(A): Area, Age and Gender Wise Distribution of Study Sample for Scores of Cpitn in Rural Population

\begin{tabular}{|c|c|c|c|c|c|c|c|c|c|c|}
\hline \multirow{2}{*}{$\begin{array}{l}\text { Age } \\
\text { group }\end{array}$} & \multicolumn{2}{|c|}{0} & \multicolumn{2}{|c|}{1} & \multicolumn{2}{|c|}{2} & \multicolumn{2}{|c|}{3} & \multicolumn{2}{|c|}{4} \\
\hline & Male & Female & Male & Female & Male & Female & Male & Female & Male & Female \\
\hline $\begin{array}{c}\text { 20- } \\
\text { 30yrs }\end{array}$ & $\begin{array}{c}8 \\
(7.2 \%)\end{array}$ & $\begin{array}{c}7 \\
(6.4 \%)\end{array}$ & $\begin{array}{c}14 \\
(6 \%)\end{array}$ & $\begin{array}{c}24 \\
(\mathbf{2 2 . 2 \%})\end{array}$ & $\begin{array}{c}66 \\
(\mathbf{5 9} \%)\end{array}$ & $\begin{array}{c}50 \\
(46 \%)\end{array}$ & $\begin{array}{c}9 \\
(\mathbf{8 . 1 \%})\end{array}$ & $\begin{array}{c}9 \\
(\mathbf{8 . 3 \%})\end{array}$ & $\begin{array}{c}19 \\
(\mathbf{1 7 . 7 \%})\end{array}$ & $\begin{array}{c}18 \\
(\mathbf{1 6 . 6 \% )}\end{array}$ \\
\hline $\begin{array}{c}\text { 30-40 } \\
\text { yrs }\end{array}$ & $\begin{array}{c}12 \\
(\mathbf{1 2 . 3 \%})\end{array}$ & $\begin{array}{c}2 \\
(2.3 \%)\end{array}$ & $\begin{array}{c}17 \\
\mathbf{( 1 2 . 1 \% )}\end{array}$ & $\begin{array}{c}9 \\
(10.1 \%)\end{array}$ & $\begin{array}{c}39 \\
\mathbf{( 4 3 . 3 \% )}\end{array}$ & $\begin{array}{c}40 \\
(\mathbf{4 7 . 1 \% )}\end{array}$ & $\begin{array}{c}11 \\
\mathbf{( 7 . 1 \% )}\end{array}$ & $\begin{array}{c}6 \\
(7.5 \%)\end{array}$ & $\begin{array}{c}25 \\
(\mathbf{2 5 . 2 \%})\end{array}$ & $\begin{array}{c}20 \\
(\mathbf{3 2 . 9 \%})\end{array}$ \\
\hline $\begin{array}{c}40-50 \\
\text { yrs }\end{array}$ & $\begin{array}{c}7 \\
(\mathbf{1 2 . 5} \%)\end{array}$ & $\begin{array}{c}4 \\
(6.7 \%)\end{array}$ & $\begin{array}{c}5 \\
(8.6 \%)\end{array}$ & $\begin{array}{c}6 \\
(\mathbf{1 0 \%})\end{array}$ & $\begin{array}{c}20 \\
(\mathbf{3 4 . 5 \%})\end{array}$ & $\begin{array}{c}22 \\
(\mathbf{3 6 . 6 \%})\end{array}$ & $\begin{array}{c}11 \\
(\mathbf{1 2 . 9 \%})\end{array}$ & $\begin{array}{c}4 \\
(6.7 \%)\end{array}$ & $\begin{array}{c}18 \\
(\mathbf{3 1 . 5 \%})\end{array}$ & $\begin{array}{c}24 \\
(\mathbf{4 0 \%})\end{array}$ \\
\hline \multirow[t]{2}{*}{$\begin{array}{c}50 \text { and } \\
\text { above } \\
\text { yrs }\end{array}$} & $\begin{array}{c}0 \\
(0 \%)\end{array}$ & $\begin{array}{c}0 \\
(0 \%)\end{array}$ & $\begin{array}{c}7 \\
(\mathbf{1 1 \%})\end{array}$ & $\begin{array}{c}7 \\
(\mathbf{1 2 \%} \%)\end{array}$ & $\begin{array}{c}20 \\
(\mathbf{3 1 \%})\end{array}$ & $\begin{array}{c}17 \\
(26 \%)\end{array}$ & $\begin{array}{c}7 \\
\mathbf{( 1 2 . 1 \% )}\end{array}$ & $\begin{array}{c}9 \\
(14.2 \%)\end{array}$ & $\begin{array}{c}26 \\
(\mathbf{4 6 \%})\end{array}$ & $23(41 \%)$ \\
\hline & \multicolumn{2}{|c|}{$\begin{array}{c}\chi_{(\mathrm{cal})}^{2}=11.923 \\
\chi_{(3,01)}^{2}=11.14 \\
\mathbf{p}<.01 * \text { (sig) }\end{array}$} & \multicolumn{2}{|c|}{$\begin{array}{c}\chi_{(\mathrm{cal})}^{2}=11.5923 \\
\chi_{(3,01)}^{2}=11.345 \\
\mathbf{p}^{<<01 *(\mathrm{sig})}\end{array}$} & \multicolumn{2}{|c|}{$\begin{array}{c}\chi_{(\mathrm{cal})=12.0321}^{2} \\
\chi_{(3,01)}^{2}=11.34 \\
\mathbf{p}<.01 *(\mathrm{sig})\end{array}$} & \multicolumn{2}{|c|}{$\begin{array}{c}\chi_{(\mathrm{cal})}^{2}=13.581 \\
\chi_{(3, .01)}^{2}=11.345 \\
\mathbf{p}<.01^{*}(\mathrm{sig})\end{array}$} & \multicolumn{2}{|c|}{$\begin{array}{c}\chi_{(\mathrm{cal})}^{2}=18.1129 \\
\chi_{(3, .01)}^{2^{2}}=\mathbf{1 1 . 3 4 5} \\
\mathbf{p}<.01^{*}(\mathrm{sig})\end{array}$} \\
\hline
\end{tabular}

Table No.1 (B): Area, Age and Gender Wise Distribution of Study Sample for Scores of Cpitn in Urban Population

\begin{tabular}{|c|c|c|c|c|c|c|c|c|c|c|}
\hline \multirow{2}{*}{$\begin{array}{l}\text { Age } \\
\text { Group }\end{array}$} & \multicolumn{2}{|c|}{$\mathbf{0}$} & \multicolumn{2}{|c|}{1} & \multicolumn{2}{|c|}{2} & \multicolumn{2}{|c|}{3} & \multicolumn{2}{|c|}{4} \\
\hline & Male & Female & Male & Female & Male & Female & Male & Female & Male & Female \\
\hline $\begin{array}{c}20-30 \\
\text { yrs }\end{array}$ & $\begin{array}{c}15 \\
(\mathbf{1 4 . 8 \% )}\end{array}$ & $\begin{array}{c}10 \\
(\mathbf{1 2 . 2 \%})\end{array}$ & $\begin{array}{c}18 \\
(\mathbf{1 7 . 9 \% )}\end{array}$ & $\begin{array}{c}12 \\
(\mathbf{1 9 . 5 \% )}\end{array}$ & $56(\mathbf{5 5 \%} \%)$ & $\begin{array}{c}30 \\
(32.2 \%)\end{array}$ & $\begin{array}{c}10 \\
(9.9 \%)\end{array}$ & $\begin{array}{c}13 \\
\mathbf{( 1 4 . 1 \% )}\end{array}$ & $\begin{array}{c}21 \\
(2.7 \%)\end{array}$ & $\begin{array}{c}27 \\
(\mathbf{2 2 \%})\end{array}$ \\
\hline $\begin{array}{c}30-40 \\
\text { yrs }\end{array}$ & $\begin{array}{c}5 \\
(5.5 \%)\end{array}$ & $\begin{array}{c}2 \\
(2.8 \%)\end{array}$ & $\begin{array}{c}11 \\
(\mathbf{1 0 . 7 \%})\end{array}$ & $\begin{array}{c}11 \\
(\mathbf{1 5 . 7 \%})\end{array}$ & $\begin{array}{c}37 \\
(36.3 \%)\end{array}$ & $\begin{array}{c}27 \\
(38.6 \%)\end{array}$ & $\begin{array}{c}15 \\
(\mathbf{1 4 . 7 \%})\end{array}$ & $\begin{array}{c}14 \\
(20 \%)\end{array}$ & $\begin{array}{c}34 \\
(33.3 \%)\end{array}$ & $\begin{array}{c}16 \\
(22.8 \%)\end{array}$ \\
\hline $\begin{array}{c}40-50 \\
\text { yrs }\end{array}$ & $\begin{array}{c}6 \\
(5.6 \%)\end{array}$ & $\begin{array}{c}3 \\
(6.9 \%)\end{array}$ & $6(5.6 \%)$ & $\begin{array}{c}4 \\
(9.3 \%)\end{array}$ & $\begin{array}{c}46 \\
(\mathbf{4 1 . 3 \% )}\end{array}$ & $\begin{array}{c}19 \\
(\mathbf{4 4 . 1 \%} \%\end{array}$ & $\begin{array}{c}6 \\
(5.6 \%)\end{array}$ & $\begin{array}{c}2 \\
(4.6 \%)\end{array}$ & $\begin{array}{c}44 \\
\mathbf{( 4 1 . 5 \% )}\end{array}$ & $\begin{array}{c}15 \\
(\mathbf{3 4 . 8 \% )}\end{array}$ \\
\hline \multirow[t]{2}{*}{$\begin{array}{c}50 \text { and } \\
\text { above } \\
\text { yrs }\end{array}$} & $\begin{array}{c}1 \\
\mathbf{( 1 . 5 \% )}\end{array}$ & $\begin{array}{c}0 \\
(0 \%)\end{array}$ & $\begin{array}{c}8 \\
(\mathbf{1 8 . 4 \% )}\end{array}$ & $\begin{array}{c}10 \\
(\mathbf{1 5 . 8 \%})\end{array}$ & $18(\mathbf{2 8 \%})$ & $\begin{array}{c}28 \\
(\mathbf{4 4 . 4 \% )}\end{array}$ & $\begin{array}{c}9 \\
(\mathbf{1 4 . 3} \%)\end{array}$ & $4(6.3 \%)$ & $24(38 \%)$ & $\begin{array}{c}21 \\
(\mathbf{3 3 . 3} \%)\end{array}$ \\
\hline & \multicolumn{2}{|c|}{ 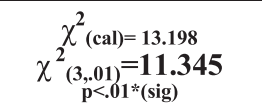 } & \multicolumn{2}{|c|}{ 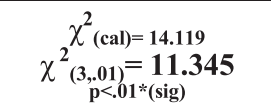 } & \multicolumn{2}{|c|}{ 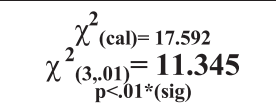 } & \multicolumn{2}{|c|}{$\begin{array}{c}\chi_{(\mathrm{cal})=}^{2}=18.211 \\
\chi_{(3,01)}^{2^{2}}=11.345 \\
\mathrm{p}<.01^{*}(\mathrm{sig})\end{array}$} & \multicolumn{2}{|c|}{$\begin{array}{c}\chi_{(\mathrm{cal})=}^{2}=14.311 \\
\chi_{(3,01)}^{2^{2}}=11.345 \\
\mathbf{p}<.01^{*}(\mathrm{sig})\end{array}$} \\
\hline
\end{tabular}

By applying CHI-square statistics; significant association was observed between males and females having different scores of C.P.I.T.N from rural and urban areas in different age groups

age group was made it was found that $55 \%$ of males; and $32.2 \%$ of females from urban areas and $59 \%$ of males and $46 \%$ of females from rural areas had C.P.I.T.N code 2. Again in 30-40 yrs age group; $43.3 \%$ of males and $47.1 \%$ of females and $36.3 \%$ of males and $38.6 \%$ of females had CPITN code 2 from rural and urban areas; respectively.

In 40-50yrs age group CPITN code 2 along with CPITN code 4 was found to be significantly higher in both the urban and rural areas; but $46 \%$ of males and $41 \%$ of females from rural areas and $42 \%$ of males and $33.3 \%$ of females from urban areas had code 4 in 50 years and above age group.
In rural areas; $17.7 \%$ of males had CPITN code 4 in comparison to urban males $(2.7 \%)$ in the age group of 20-30 years. In urban areas, CPITN code 0 for females was significantly higher as compared to rural females. In both the rural and urban areas code 3 and 4 showed higher values with increase in age.

When the subjects were examined for different severity scores of E.S.I $\{$ Table No $2(\mathrm{~A}) \&(\mathrm{~B})\}$ it was noticed that in the age group of $20-30$ years; only $19.8 \%$ of males; and $18.5 \%$ of females had attachment loss of $1-3 \mathrm{~mm}$. while $15.3 \%$ of males and $12 \%$ of females had attachment loss of more than $3 \mathrm{~mm}$ in rural areas. $22.8 \%$ 
Table No 2(A): Area, Age and Gender Wise Distribution of Study Sample for Scores of E.S.I in Rural Population

\begin{tabular}{|c|c|c|c|c|c|c|c|}
\hline \multirow{2}{*}{ Age Group } & \multirow[t]{2}{*}{ Gender } & \multicolumn{2}{|c|}{$1-3 \mathrm{~mm}$} & \multicolumn{2}{|c|}{$>3 \mathrm{~mm}$} & \multirow{2}{*}{\multicolumn{2}{|c|}{$0 \mathrm{~mm}$}} \\
\hline & & $=30 \%$ & $>30 \%$ & $=\mathbf{3 0} \%$ & $>30 \%$ & & \\
\hline \multirow{2}{*}{ 20-30 yrs } & Male & $\begin{array}{c}1 \\
(0.9 \%)\end{array}$ & $\begin{array}{c}22 \\
(\mathbf{1 9 . 8 \%})\end{array}$ & $0(0 \%)$ & $\begin{array}{c}17 \\
(\mathbf{1 5 . 3 \%})\end{array}$ & $\begin{array}{c}71 \\
(63.9 \%)\end{array}$ & \multirow[t]{2}{*}{ p $<.01 *$ (sig) } \\
\hline & Female & $0(\mathbf{0 \%})$ & $\begin{array}{c}20 \\
(\mathbf{1 8 . 5 \%}) \\
\end{array}$ & $0(0 \%)$ & $\begin{array}{c}13 \\
(\mathbf{1 2 \%} \%) \\
\end{array}$ & $\begin{array}{c}75 \\
(69.4 \%) \\
\end{array}$ & \\
\hline \multirow{2}{*}{$30-40$ yrs } & Male & $3(3 \%)$ & $\begin{array}{c}24 \\
(24 \%) \\
\end{array}$ & $0(0 \%)$ & $\begin{array}{c}11 \\
(\mathbf{1 1 . 8 \%})\end{array}$ & $\begin{array}{c}61 \\
(61.2 \%) \\
\end{array}$ & \multirow[t]{2}{*}{ p $<.01 *$ (sig) } \\
\hline & Female & $\begin{array}{c}3 \\
(3.5 \%) \\
\end{array}$ & $\begin{array}{c}24 \\
(28.2 \%) \\
\end{array}$ & $0(0 \%)$ & $\begin{array}{c}16 \\
(\mathbf{1 8 . 8 \%}) \\
\end{array}$ & $\begin{array}{c}42 \\
(\mathbf{4 9 . 4 \% )} \\
\end{array}$ & \\
\hline \multirow{2}{*}{$40-50$ yrs } & Male & $\begin{array}{c}3 \\
(5.2 \%) \\
\end{array}$ & $\begin{array}{c}20 \\
(\mathbf{3 4 . 5 \%}) \\
\end{array}$ & $0(\mathbf{0} \%)$ & $\begin{array}{c}10 \\
(\mathbf{1 7 . 2 \%})\end{array}$ & $\begin{array}{c}25 \\
(\mathbf{4 3 . 1 \%}) \\
\end{array}$ & \multirow[t]{2}{*}{ p $<.01 *$ (sig) } \\
\hline & Female & $0(0 \%)$ & $\begin{array}{c}25 \\
(41.7 \%) \\
\end{array}$ & $0(\mathbf{0} \%)$ & $\begin{array}{c}14 \\
(23.3 \%) \\
\end{array}$ & $\begin{array}{c}21 \\
(35 \%) \\
\end{array}$ & \\
\hline \multirow{2}{*}{$\begin{array}{c}50 \text { yrs and } \\
\text { above }\end{array}$} & Male & $\begin{array}{c}11 \\
(\mathbf{1 5 \%}) \\
\end{array}$ & $\begin{array}{c}25 \\
(\mathbf{3 4 . 2 \% )} \\
\end{array}$ & $0(0 \%)$ & $\begin{array}{c}19 \\
(26 \%) \\
\end{array}$ & $\begin{array}{c}18 \\
(\mathbf{2 4 . 6 \% )} \\
\end{array}$ & \multirow[t]{2}{*}{ p $<.01 *$ (sig) } \\
\hline & Female & $0(\mathbf{0} \%)$ & $\begin{array}{c}10 \\
(\mathbf{2 0 . 8 \%})\end{array}$ & $0(0 \%)$ & $\begin{array}{c}25 \\
(52 \%) \\
\end{array}$ & $\begin{array}{c}13 \\
(27 \%) \\
\end{array}$ & \\
\hline
\end{tabular}

Table No 2(B): Area, Age and Gender Wise Distribution of Study Sample for Scores of E.S.I in Urban Population

\begin{tabular}{|c|c|c|c|c|c|c|c|}
\hline \multirow{4}{*}{$\begin{array}{c}\text { Age Groups } \\
20-30 \text { yrs }\end{array}$} & \multirow{3}{*}{$\begin{array}{l}\text { Gender } \\
\text { Male }\end{array}$} & \multicolumn{2}{|c|}{ 1-3 mm } & \multicolumn{2}{|c|}{$>3 \mathrm{~mm}$} & \multirow{2}{*}{\multicolumn{2}{|c|}{$0 \mathrm{~mm}$}} \\
\hline & & \multirow{2}{*}{$\begin{array}{c}\begin{array}{c}=30 \% \\
\text { of sites }\end{array} \\
3 \\
(\mathbf{2 . 8 \%}) \\
\end{array}$} & \multirow{2}{*}{$\begin{array}{c}\begin{array}{c}>30 \% \text { of } \\
\text { sites }\end{array} \\
23 \\
(22.8 \%)\end{array}$} & \multirow{2}{*}{$\begin{array}{l}=30 \% \\
\text { of sites }\end{array}$} & \multirow{2}{*}{$\begin{array}{c}\begin{array}{c}>\mathbf{3 0} \% \text { of } \\
\text { sites }\end{array} \\
15 \\
(13.9 \%)\end{array}$} & & \\
\hline & & & & & & $\begin{array}{c}60 \\
(60.6 \%)\end{array}$ & \multirow{2}{*}{$p<.01 *($ sig $)$} \\
\hline & Female & $0(\mathbf{0 \%})$ & $\begin{array}{c}27 \\
(\mathbf{2 9 . 3 \% )}\end{array}$ & $0(0 \%)$ & $\begin{array}{c}11 \\
(\mathbf{1 1 . 9 \% )}\end{array}$ & $\begin{array}{c}54 \\
\mathbf{( 5 8 . 7 \% )}\end{array}$ & \\
\hline \multirow{2}{*}{$30-40$ yrs } & Male & $0(\mathbf{0 \%})$ & $\begin{array}{c}37 \\
(36.3 \%)\end{array}$ & $0(0 \%)$ & $\begin{array}{c}20 \\
(\mathbf{1 9 . 6 \% )}\end{array}$ & $\begin{array}{c}45 \\
(44.1 B)\end{array}$ & \multirow{2}{*}{$\mathrm{p}<.01$ * $(\mathrm{sig}$} \\
\hline & Female & $0(0 \%)$ & $\begin{array}{c}16 \\
(22.8 \%)\end{array}$ & $0(\mathbf{0 \%})$ & $\begin{array}{c}23 \\
(32.8 \%)\end{array}$ & $\begin{array}{c}31 \\
\mathbf{( 4 4 . 3 \% )}\end{array}$ & \\
\hline \multirow{2}{*}{$40-50$ yrs } & Male & $0(0 \%)$ & $\begin{array}{c}47 \\
(44 \%)\end{array}$ & $0(0 \%)$ & $\begin{array}{c}25 \\
(26 \%)\end{array}$ & $\begin{array}{c}32 \\
(\mathbf{3 0 . 1} \%)\end{array}$ & \multirow{2}{*}{$\mathrm{p}<.01 *(\mathrm{sig})$} \\
\hline & Female & $0(\mathbf{0 \%})$ & $\begin{array}{c}18 \\
(\mathbf{4 1 . 9 \% )} \\
\end{array}$ & $0(0 \%)$ & $\begin{array}{c}9 \\
(20.9 \%) \\
\end{array}$ & $\begin{array}{c}16 \\
(37.2 \%) \\
\end{array}$ & \\
\hline \multirow{2}{*}{$\begin{array}{l}50 \text { yrs and } \\
\text { above urban }\end{array}$} & Male & $0(0 \%)$ & $\begin{array}{c}28 \\
(34.5 \%)\end{array}$ & $0(\mathbf{0 \%})$ & $\begin{array}{c}27 \\
(\mathbf{3 3 . 3} \%)\end{array}$ & $\begin{array}{c}26 \\
(32 \%)\end{array}$ & \multirow{2}{*}{$\mathrm{p}<.01 *$ (sig } \\
\hline & Female & $0(\mathbf{0 \%})$ & $\begin{array}{c}21 \\
(33 \%)\end{array}$ & $0(0 \%)$ & $\begin{array}{c}13 \\
(20.6 \%)\end{array}$ & $\begin{array}{c}29 \\
(46 \%)\end{array}$ & \\
\hline
\end{tabular}

A significant association was observed between males and females in 1-3mm group but in $>3 \mathrm{~mm}$ group non -significant association was observed in E.S.I severity in rural population. In urban areas a nonsignificant association was observed in different groups $(1-3 \mathrm{~mm} \&>3 \mathrm{~mm})$. While in $0 \mathrm{~mm}$ group a significant association was seen in both areas in different age groups.

of males and $29.3 \%$ of females had attachment loss of $1-3 \mathrm{~mm}$ from urban areas in the age same group.

In urban areas $19.6 \%$ of males and $32.8 \%$ of females had attachment loss of more than $3 \mathrm{~mm}$ as compared to $11.8 \%$ of males and $18.8 \%$ of females, respectively in rural areas in the age group of 30-40 years.
In $40-50$ years age group; $34.5 \%$ of males and $41.7 \%$ of females from rural areas and $44 \%$ of males and $41.9 \%$ of females from urban areas had attachment loss of $1-3 \mathrm{~mm}$, while $17.2 \%$ of males and $23.3 \%$ of females from rural areas and $26.3 \%$ of males and $20.9 \%$ of females from urban areas had attachment loss of more than $3 \mathrm{~mm}$. This shows that urban males had higher 
attachment loss as compared to rural males.

In 50 years and above age group $33.3 \%$ of males from urban areas had attachment loss of more than $3 \mathrm{~mm}$ as compared to $26 \%$ rural males; while $52 \%$ of rural females had attachment loss of more than $3 \mathrm{~mm}$ as compared to $20.6 \%$ urban females. The above results show that urban males had a higher loss of attachment as compared to rural males and rural females had higher loss of attachment as compared to urban females. More number of healthy sites were noticed in young individuals from both the genders.

\section{DISCUSSION}

A cross-sectional survey was done by using multistage sampling procedure. Sampling method is a critical issue in descriptive type of epidemiological surveys to assess the true magnitude of the disease; sample population is expected to represent the whole population without any bias. Total of 1300 subjects were assessed to evaluate their periodontal status using disease identification indices i.e. - CPITN and ESI. Out of the total 1300 subjects evaluated, 658 were from urban population and 642 were from rural population. 341 males and 301 females were assessed from rural population while390 males and 268 females were assessed from urban population.

Extent and Severity Index indicated that 51\% males and $50 \%$ females from rural areas and $41.7 \%$ of urban males and $48.5 \%$ of urban females were free from chronic periodontitis. So, overall $57 \%$ of males and $51 \%$ of females had chronic periodontitis as estimated by E.S.I index. When following the code 3 and 4 of C.P.I.T.N index, $36 \%$ of rural males, $38 \%$ of rural females and $42.5 \%$ of urban males, $41.7 \%$ of urban females proved to be suffering from chronic periodontitis. The results of CPITN show that CPITN index has given an incorrect estimate of prevalence of periodontal disease. These results are in accordance with the reports of Lewis. ${ }^{10,11}$

Further, percentage of population suffering from periodontitis increased with age. The females and males with CPITN Code 4 were $16.6 \%$ and $17.7 \%$ (20$30 \mathrm{yrs}$ ), 32.9\%/25.2\% (30-40 yrs), 40\%/31\% (40-50 $\mathrm{yrs}$ ), $41 \% / 46 \%$ (50yrs and above) respectively. Almost similar trend was observed in urban population. Highest percentage of subjects with CPITN Code 4 was observed in 50 years and above. Maximum numbers of healthy subjects i.e. Code 0 were observed among 4050 years of rural females and 30-40 years of urban female.

Distribution of study sample under different severities of loss of attachment observed was as under: percentage of healthy sites without any loss of attachment was maximum in youngest age group rural males and females with values $63.9 \%$ and $69.4 \%$; respectively and the same was true for healthy sites in urban males and females with values $60.6 \%$ and $58.7 \%$; respectively. The disease sites with moderate loss of attachment $(>3 \mathrm{~mm})$ were highest in 50 years and above rural males $(26 \%)$ as well as rural females $(52 \%)$ and urban males (33.3\%). Unusual change was observed in urban females and rural females in which the maximum percentage with loss of attachment was observed in 4050 years age group with values of $41.9 \%$ and $41.7 \%$; respectively. The disease sites with mild loss of attachment (1-3mm) were highest in 40-50 yrs and 50 years and above age group in both the areas. These observations indicate consistent age related changes in loss of attachment in majority of the rural and urban males and females in different age groups which was not there in CPITN index. Jenny M. Lewis et $\mathrm{al}^{10}$ questioned the validity of Community Periodontal Index for Treatment Needs scoring and presentation method for measuring periodontal conditions. Thus; the results of the study clearly shows the underestimation of the disease when examined with C.P.I.T.N index but we need accurate data to demonstrate how cross- sectional surveys estimate the disease load in presence of risk factors when associated with the disease of interest.

\section{CONCLUSION}

Based on the results of this study, following conclusions can be drawn:

1. Periodontal disease was found to be highly prevalent in the study population and severity of disease increased with age. More number of subjects in younger age group were found to be healthy.

2. Severity of the disease can be more accurately examined by ESI index rather than CPITN index. 


\section{INFORMED CONSENT STATEMENT}

\section{INSTITUTE OF DENTAL STUDIES AND TECHNOLOGIES}

\section{DEPARTMENT OF PERIODONTICS}

\section{PERFORMA NO.1}

I undersigned; give my consent to carry out any examination, investigation as deemed necessary by doctor concerned.

(Patient's Signature)

NAME:

AGE/SEX:

EDUCATIONAL STATUS:

OCCUPATION/INCOME:

ADDRESS:

CHIEF COMPLAINT:

MEDICAL HISTORY:

ORAL HYGIENE: $\quad$ a) TOOTH BRUSH b) FINGER c) DATUN d) MOUTH RINSING e) OTHERS

FREQUENCY: $\quad$ a) ONCE b) TWICE c) OCCASSIONALY

DENTIFRICES: $\quad$ a) TOOTH PASTE b) TOOTH POWDER c) OTHERS

HABITS: $\quad$ a) SMOKING b) CHEWING TOBACCO c) PAN d) OTHERS

ORAL HYGINE STATUS:

A) DEBRIS INDEX

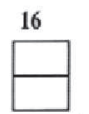

46

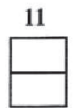

31

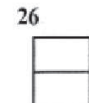

36

Good (0.0-0.6) / Fair (0.7-1.8) / Poor (1.9-3.0)
Score

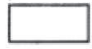

B) CALCULUS INDEX

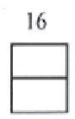

46

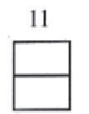

31

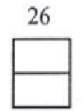

36
Score

Good (0.0-0.6) / Fair (0.7-1.8) / Poor (1.9-3.0)

OHI-S = DI-S + Cl-S Score
0 - No debris or stains present

$1-$ Soft debris covering not more than one third of tooth surface being examined or the presence of extrinsic stains without debris regardless of surface area covered

2 - Soft debris covering more than one third but not more than two third of exposed tooth surface

3 - Soft debris covering more than two third of exposed tooth surface

0 - No calculus present

1 - supragingival calculus covering not more than one third of the exposed tooth surface being examined

2 - Supragingival calculus covering more than one third but not more than two third of exposed tooth surface or the presence of individual flecks of subgingival calculus around the cervical portion of tooth

3 - Supragingival calculus covering more than two third of the exposed tooth surface or a continuous heavy band of subgingival calculus around the cervical portion of the tooth

Good (0.0-1.2) / Fair (1.3-3.0) / Poor (3.1-6.0) 
CPITN INDEX

\begin{tabular}{|c|c|c|c|c|c|}
\hline CODE & & & & & \\
\hline INDEXTEETH & 17 & 16 & 11 & 26 & 27 \\
\hline INDEXTEETH & 47 & 46 & 31 & 36 & 37 \\
\hline CODE & & & & & \\
\hline
\end{tabular}

CODE

Pathologic pockets $6 \mathrm{~mm}$ or deeper (Code 4), Pathologic pockets 4 or $5 \mathrm{~mm}$ deep (Code 3), Supra-or subgingival calculus (Code 2), Gingival bleeding after gentle probing (Code 1), No signs of disease (Code 0).

TREATMENT NEEDS:

$0=$ No treatment $($ Code- 0$), I=I$ mprovement in personal oral hygiene $($ Code 1$), I I=I+$ scaling $($ Code 2 and 3$), I I I=I+I I+$ Complex treatment (Code-4)

\section{EXTENT AND SEVERITY INDEX}

\begin{tabular}{|c|c|c|c|c|c|c|c|c|c|c|c|c|c|c|}
\hline TEETH & 17 & 16 & 15 & 14 & 13 & 12 & 11 & 21 & 22 & 23 & 24 & 25 & 26 & 27 \\
\hline \multirow{2}{*}{$\begin{array}{c}\text { LOSS OF } \\
\text { ATTACHMENT }\end{array}$} & B & B & B & B & B & B & B & MB & MB & MB & MB & MB & MB & MB \\
\hline & MB & MB & MB & MB & MB & MB & MB & B & B & B & B & B & B & B \\
\hline \multirow{2}{*}{$\begin{array}{c}\text { LOSS OF } \\
\text { ATTACHMENT }\end{array}$} & MB & MB & MB & MB & MB & MB & MB & B & B & B & B & B & B & B \\
\hline & B & B & B & B & B & B & B & MB & MB & MB & MB & MB & MB & MB \\
\hline TEETH & 47 & 46 & 45 & 44 & 43 & 42 & 41 & 31 & 32 & 33 & 34 & 35 & 36 & 37 \\
\hline
\end{tabular}

\section{EXTENT $=\underline{\text { N0. OF SITES WITH LPA }>1 \mathrm{~mm} \times 100}$ \\ NO. OF SITES EXAMINED \\ SEVERITY = MEAN OF SITE EXAMINED WITH LPA $>1 \mathrm{~mm}$}

GINGIVAL MARGIN TO BASE OF POCKET(MIDBUCCALY AND MESIOBUCCALY)

\begin{tabular}{|c|c|c|c|c|c|c|c|c|c|c|c|c|c|c|}
\hline TEETH & 17 & 16 & 15 & 14 & 13 & 12 & 11 & 21 & 22 & 23 & 24 & 25 & 26 & 27 \\
\hline \multirow[t]{2}{*}{ GM-BOP } & B & B & B & B & B & B & B & MB & MB & MB & MB & MB & MB & MB \\
\hline & MB & MB & MB & MB & MB & MB & MB & B & B & B & B & B & B & B \\
\hline \multirow[t]{2}{*}{ GM-BOP } & MB & MB & MB & MB & MB & MB & MB & B & B & B & B & B & B & B \\
\hline & B & B & B & B & B & B & B & MB & MB & MB & MB & MB & MB & MB \\
\hline TEETH & 47 & 46 & 45 & 44 & 43 & 42 & 41 & 31 & 32 & 33 & 34 & 35 & 36 & 37 \\
\hline
\end{tabular}

GINGIVAL MARGIN TO CEMENTOENAMEL JUNCTION (MIDBUCCALY AND MESIOBUCCALY)

\begin{tabular}{|c|c|c|c|c|c|c|c|c|c|c|c|c|c|c|}
\hline TEETH & 17 & 16 & 15 & 14 & 13 & 12 & 11 & 21 & 22 & 23 & 24 & 25 & 26 & 27 \\
\hline GM-CEJ & $\begin{array}{l}\text { B } \\
\text { MB }\end{array}$ & $\begin{array}{l}\text { B } \\
\text { MB }\end{array}$ & $\begin{array}{l}\text { B } \\
\text { MB }\end{array}$ & $\begin{array}{l}\text { B } \\
\text { MB }\end{array}$ & $\begin{array}{l}\text { B } \\
\text { MB }\end{array}$ & $\begin{array}{l}\text { B } \\
\text { MB }\end{array}$ & $\begin{array}{l}\text { B } \\
\text { MB }\end{array}$ & $\begin{array}{l}\text { MB } \\
\text { B }\end{array}$ & $\begin{array}{l}\text { MB } \\
\text { B }\end{array}$ & $\begin{array}{l}\text { MB } \\
\text { B }\end{array}$ & $\begin{array}{l}\text { MB } \\
\text { B }\end{array}$ & $\begin{array}{l}\text { MB } \\
\text { B }\end{array}$ & $\begin{array}{l}\text { MB } \\
\text { B }\end{array}$ & $\begin{array}{l}\text { MB } \\
\text { B }\end{array}$ \\
\hline GM-CEJ & $\begin{array}{l}\text { MB } \\
\text { B }\end{array}$ & $\begin{array}{l}\text { MB } \\
\text { B }\end{array}$ & $\begin{array}{l}\text { MB } \\
\text { B }\end{array}$ & $\begin{array}{l}\text { MB } \\
\text { B }\end{array}$ & $\begin{array}{l}\text { MB } \\
\text { B }\end{array}$ & $\begin{array}{l}\text { MB } \\
\text { B }\end{array}$ & $\begin{array}{l}\text { MB } \\
\text { B }\end{array}$ & $\begin{array}{l}\text { B } \\
\text { MB }\end{array}$ & $\begin{array}{l}\text { B } \\
\text { MB }\end{array}$ & $\begin{array}{l}\text { B } \\
\text { MB }\end{array}$ & $\begin{array}{l}\text { B } \\
\text { MB }\end{array}$ & $\begin{array}{l}\text { B } \\
\text { MB }\end{array}$ & & $\begin{array}{l}\text { B } \\
\text { MB }\end{array}$ \\
\hline TEETH & 47 & 46 & 45 & 44 & 43 & 42 & 41 & 31 & 32 & 33 & 34 & 35 & 36 & 37 \\
\hline
\end{tabular}




\section{REFERENCES}

1) Albandar JM. Epidemiology and Risk Factors of Periodontal Diseases. Dent Clin North Am 2005; 49(3):517-32.

2) Beck JD \&Loe H. Epidemiological Principles in Studying Periodontal Diseases. Periodontol 2000 1993;2(1):34-45.

3) Khamrco TY. Assessment of periodontal diseases using the CPITN index in a rural population in Ninevah, lraq. East Mediterr Health J 1999; 5(3): 549-55.

4) Ainamo J, Ainamo A. Partial indices as indicators of the severity and prevalence of periodontal disease. Int Dent J 1985; 35: 322-26.

5) Brown LJ \& Loe H.Prevalence, extent, severity and progression of periodontal disease. Periodontol 2000; 1993(2): 57-71.

6) Rao SP, Bharambe MS. Dental Caries and Periodontal Disease among Urban. Rural and Tribal School Children. Indian Pediatrics 1993; 30(6): 759-64.
7) Fisher, RonaldA.; Yates, Frank Statistical tables for biological, agricultural and medical research $3^{\text {rd }}$ ed (1938): 26-7.

8) Pilot $\mathrm{T}$, Barmes DE, Leclercq MH, Mc Combie BJ, Sardo Infirri J: Periodontal conditions in adolescents, 15-19 years of age: An overview of CPITN data in the WHO Global oral Data Bank. Community Dent Oral Epidemiol 1987; 15: 336-8.

9) Carlos JP, Wolfe MD and Kingman A: The extent and severity index a simple method for use in epidemiologic studies of periodontal disease. J Clin Periodontol 1986; 13: 500-5.

10) Lewis JM, Morgan MV, Wright FAC. The validity of CPITN scoring and Presentation method for measuring periodontal conditions. J Clin Periodontol 1994; 21:1-6.

11) Benigeri M, Brodeur JM, Payette $M$, Charbonneau A, Ismail A.L.CPITN and prevalence of periodontal conditions. J Clinc Periodontol 2000; 27: 308-12.

Source of Support: Nil, Conflict of Interest: None Declared 